\title{
The meaning of work: perspectives of nursing professionals who work in clinical units
}

\author{
Significado do trabalho: perspectivas de profissionais de enfermagem atuantes em unidades \\ clínicas
}

Patrícia de Castro Barboza ${ }^{1}$, Ariane da Silva Pires ${ }^{1}$, Eugenio Fuentes Pérez Júnior ${ }^{1}$, Elias Barbosa de Oliveira ${ }^{1}$, Tiago Braga do Espírito Santo ${ }^{1}$, Cristiane Helena Gallasch ${ }^{1}$

Objective: to understand the meaning of work, from the perspective of nursing professionals. Methods: qualitative research, conducted in a clinical inpatient unit of a university hospital. The study included 20 nursing professionals contacted through semi-structured interviews. The data were analyzed through the thematic content analysis technique, emerging the categories: perspectives and meanings attributed to the world of work by nursing professionals and situations that cause pleasure and suffering and their influences in the health-disease process of workers. Results: one identified positive and negative aspects inherent to the nursing work in the hospital environment and highlighted the illness that comes with the working process. Conclusion: the experiences of pleasure and pain are inherent to the context of nursing professionals who work in hospital environments and contribute to a search for better conditions of work place and quality of life for these professionals.

Descriptors: Nursing; Work; Occupational Health.

Objetivo: compreender o significado do trabalho, sob a ótica de profissionais de enfermagem. Métodos: pesquisa qualitativa, realizada em unidades de internação clínica, de hospital universitário. Participaram do estudo 20 profissionais de enfermagem, abordados por meio de entrevista semiestruturada. Dados analisados mediante a técnica de análise de conteúdo temática, emergindo as categorias: perspectivas e significados atribuídos ao mundo do trabalho pelos profissionais de enfermagem e situações geradoras de prazer e sofrimento e respectivas influências no processo saúde-doença dos trabalhadores. Resultados: Identificaram-se aspectos positivos e negativos inerentes ao contexto do trabalho da enfermagem no ambiente hospitalar e evidenciou-se o adoecimento decorrente do processo de trabalho. Conclusão: as vivências de prazer e sofrimento são inerentes ao contexto do trabalho da enfermagem no ambiente hospitalar e contribuem para busca por melhorias no ambiente laboral e qualidade de vida de profissionais.

Descritores: Enfermagem; Trabalho; Saúde do Trabalhador.

\footnotetext{
${ }^{1}$ Universidade do Estado do Rio de Janeiro. Rio de Janeiro, RJ, Brazil. 


\section{Introduction}

Work, health and illness are connected to the life of individuals, so that occupational activity reverberates in both physical and mental health. In this perspective, work, a source of pleasure, also brings suffering to a greater or lesser extent, and it may cause damage to health workers. For people who work in the health care area this is not different ${ }^{(1)}$.

On the other hand, we know for sure that work is not only characterized as a means of material survival, as a way to survive in a consumer society. It is responsible for the integration of people in social life, it contributes to the construction of identity and subjectivity of individuals ${ }^{(2)}$. In this sense, it is considered that work improves the expression of people's subjectivity and thus rescues and promotes health. However, depending on how the organization and the working process are configured, there is potential for physical and mental illness of workers ${ }^{(3)}$.

Work can be influenced by aspects related to the institution itself or the personal characteristics of the worker, by aspects of the work environment, such as hygiene, physical structure, safety, organization and division of labor, working hours and work shifts, relationship between production and wages or also by external aspects of the work environment, such as social situation, food, transportation, housing and interpersonal interaction.

It is important to highlight that the world of work in the liberal bourgeois capitalist society, of which man is part, is increasingly competitive, due to the direction that the capitalist way of production is taking with a globalizing trend, and individuals often need to keep many labor ties, exhausting work hours and live with the uncertainty of achieving financial stability or survive these adverse contexts, being therefore, an activity marked by distress ${ }^{(4)}$.

Nursing professionals who work in the hospital area receive the interference of some factors at work, such as the rapid and continuous use of technology, the need to acquire new theoretical and practical knowledge, besides the specific nature of their work that contributes to stress in their relationship with patients and their families, in addition to the pain and death which function as enhancers of mental load. There are also aspects of organizational environment, involving hierarchy, ambiguous roles and environment considered unhealthy, causing risks to physical and mental health of these professionals ${ }^{(5)}$.

The organization of work has changed a lot over the years and because of this, it is important to reflect and discuss about the perception of nurses regarding their work contexts. Thus, the research question emerged: what are the meanings that nursing professionals from clinical inpatient units give to their work? Thus, one aimed to know the meanings that nurses who work in clinical inpatient units give to the work they perform.

\section{Methods}

This is a qualitative study, in which the setting was a university hospital, located in the city of Rio de Janeiro, Brazil, whose unit is connected to the Unified Health System and classified as high complexity level of care and that has outpatient care and hospitalization. Regarding the field of data collection, one decided for four clinical inpatient units, whose profile consists of clients with chronic diseases, cardiovascular and hematological disorders, with comprehensive care of high and medium complexity to adults and the elderly. Given the above, it is understood that these fields are relevant regarding these experiences and meanings attributed to the process and the organization of work, which influence directly the perception of professionals about the world of work in health and nursing.

The study participants were 20 nursing workers, including nurses, technicians and assistants. For the selection of the participants, the criteria used was the convenience, when it is started with a con- 
venience sample (also called voluntary sample). The inclusion criteria were: professionals who worked in medical wards, with statutory employment and who were in full exercise of their functions for more than one year in their inpatient units. It was inferred that this period was the time required for workers to know the organization and the work process in order to contribute with their knowledge abou the object of study. One excluded professionals who were away due to health problems, on vacation or who worked at the institution for less than a year ${ }^{(3-4)}$.

For being a qualitative study, one used the criterion of saturation of information, from the moment when the interviews did not bring any new data indicating the end of interviews ${ }^{(6)}$. In this type of study, the number of participants should not be the main concern of researchers, but the quality of information provided. It ratifies the importance of the survey participants to know deeply the phenomenon investigated and to have cognitive and affective conditions to provide the information ${ }^{(7)}$.

The interviews happened between May and June 2016, through a script made of an instrument for the characterization of the participants, followed by the following question: "Considering your performance as a nursing professional talk about the meaning of work in your life." In order to preserve the anonymity of the participants, codes were used starting with the letter I for the interviewee, accompanied by cardinal number $(1,2,3 \ldots 20)$, according to the order of the interviews and the professional category ( $\mathrm{N}$ for Nurse, NT for Nurse technician).

In the categorization of testimonies, the technique of thematic content analysis was used. After transcription of interviews in its entirety, the text corpus was prepared for later analysis, by sequential organization of depositions for formulated question, so as to obtain the density and/or proximity of assigned experiences and feelings aiming to achieve the results. In the second phase, there was a thorough reading of the material in order to extract the record units or thematic units, according to the homogeneity criteria, repeatability and representativeness, and the data were typed in an Excel spreadsheet. In the last moment, using the reclassification criteria and aggregation of elements, the following categories were built: perspectives and meanings attributed to the world of work by nursing professionals and situations that generate pleasure and suffering and perspectives that influence in the health-disease process of workers.

Obeying the ethical precepts, the study was approved by the Ethics Committee in Research (technical advice number 1,517,696 and Certificate of Presentation for Ethical Consideration number $55174516,2,0000,5259)$. The professionals signed an informed consent form.

\section{Results}

Concerning the characterization of the participants, the age group ranged from 26 to 49 years old and more than 50 years old. There was a prevalence of individuals between 26 and 30 years old (30.0\%), followed by those who are 50 years old $(25.0 \%)$. Concerning gender, most of the professionals were women (75.0\%). Regarding marital status, the participants were single $(40.0 \%)$ or married $(40.0 \%)$.

About the labor characteristics, $30.0 \%$ were nurses and $70.0 \%$ nursing technicians, with time of profession between one and five years $(80.0 \%)$ and with at least two jobs (65.0\%). The participants said they did not have preexisting diseases when they entered the job market and confirmed they got sick after they started working (70.0\%).

The working hours of the nursing team was 30 hours a week, most of the nursing technicians worked on-call, fulfilling a 12X60 on-call shift. The nurses in the medical clinic wards were mostly day care workers, with a workday from 07:00 a.m. to 1:00 p.m., from Monday to Friday. 
Category 1: Perspectives and meanings attributed to the world of work by nursing professionals

The category above was built with the experiences of the nursing professionals in the hospital context and it reflects the perspectives and meanings of the world of work for the participants.

Through the participants' statements and the application of the content analysis technique, the following themes were identified: economic and subsistence issues, identification and appreciation of nursing as a profession; and the possibility of professional updating through work in the nursing area. In addition to these aspects, other sources of pleasure and suffering were pointed out at work.

The question of paid work prevailed from the workers' point of view, presenting a common understanding among the participants, confirming its importance in terms of subsistence, as identified: First, I consider my profession as a guarantee of my livelihood, it pays my bills, anyway, it provides for me (I9NT). My work in my life influences in all aspects, first I think that financially I depend on it to live, I only work in one institution, it is my only bond, financially it is everything for me, where I can actually survive (I2NT). I think that working gives me the condition to be able to live, independence to get a life, to buy my things (I7N).

The dialectics of work emerged in the testimonies as a source of pleasure and suffering from the experiences in the world of work, in which the following themes were highlighted: pleasure in patients' improvement, pleasure in working with nursing and pleasure in socializing with colleagues, as experiences pointed out by the participants that corroborated the construction of a meaning of pleasure in the nursing work: In Nursing, it is very rewarding when we see our work making a difference in someone's life...money cannot buy the feeling we have when we see our work has made a difference in the person's life or in the family we have been in contact with (I3N). I like what I do, I've been doing this for many years, I do it with pleasure, I think all this has a meaning for me (I12NT). The day to day living with my coworkwers is good and I like it very much working with them (I18N).

On the other hand, there are also negative ex- periences that contribute for the construction of meanings of suffering at the nursing work, and the following themes were identifies: difficulty in dealing with patients' suffering and death and the suffering that the work conditions bring, as shown: We don't have emotional support, because nursing works with suffering 24/7, wether you want it or not patients suffer, and so do we, then dealing with this kind of suffering is not something we are prepared to have (I1NT). And also the working conditions are not the best and they make it more difficult for us, and generate suffering, and anxiety at work, mainly in nursing (I7N). We see the patients shrinking, we try to do something for them, and we know they will continue shrinking, until they don't exist anymore (I13NT).

Participants mentioned identification and the value/affinity for nursing as a profession, such as follows: I've always enjoyed the health area (I9NT). I've discovered nursing by chance, but it's a profession I like and identify myself with (I1NT).

One has also identified the possibility the possibility of professional update through the nursing work, as seen in the following testimonies: It's important for our professional growth, it's a very embracing area, which is very positive for learning (I3N). I learn and I have a lot of lessons to learn every day, learn technically and that we have to be in continuous training (I16NT).

\section{Category 2: Situations that generate pleasure and suffering and respective influences in the health- -disease process of workers}

In this category, the situations that generate pleasure and suffering at work were discussed, and also how these experiences have repercussions on the health-disease process of nursing workers. It was evidenced, through the testimonies, that the situations that generate suffering at work have influence in the health-disease process, highlighting the themes: the repercussions of work on the mental and physical health of professionals; illness and withdrawal from the work environment.

In the participants' testimonies, it was clear the psychological suffering at work in the hospital en- 
vironment due to problems such as sadness, lack of energy and anxiety among others: So, it is something like this, we keep trying, it looks like depression but it's not, I get out of bed and I come to work, but it's a definition similar to what they say about depression, you get sad, anxious, and focused on the bad side of things (I5NT). The day to day of the profession is tough, we get tired, we lose our energy, we don't have will to work, (I13NT).

The workers also reported the emotional exhaustion and illness caused by dealing with the suffering of others, an aspect inherent to the nature of the profession, as evidenced: Every day dealing with suffering of patients or the families, the person has a psychological impact (I1NT). This ends up accumulating and we show signs in our bodies, as we deal with pain, death, diseases, if we do not take care of our head, we end up getting sick too (I7N).

One has also identified in the study of the problem of leaves due to illnesses of the workers: I don't feel healthy, and I think my colleagues neither, and you can see that in the sick leaves, you see people who started working short time ago and who are already sick! Unfortunately it's like this (I1NT).

\section{Discussion}

The limitation of the study is related to the nature of the qualitative research, performed in only one scenario, therefore, it is not intended to generalize the results.

This study intends to contribute to the field of worker's health, since the results may serve as subsidies to the institutions that responsible for promoting the health of workers, because through the analysis of the results of this research, they may promote strategies that promote improvements in the nursing work, aiming at greater satisfaction and quality of life for professionals.

The reports of illness after admission to work are extremely relevant, since the incidence and progression of diseases and disabilities involve the complex relationship of socioeconomic, behavioral, demographic and psychosocial determinants ${ }^{(8-9)}$, and the salary and overall income are relevant in the interviews. The predominant incidence of musculoskeletal disorders, as well as mental changes, corroborate the results of other studies performed in public hospitals $^{(10-11)}$.

Working in the capitalist productive system, since the Industrial Revolution, has been the main source from which come the financial resources necessary for the subsistence of workers and their families and the maintenance of living conditions ${ }^{(12)}$. It should be emphasized that, currently, the changes in the world of work have promoted the global de-structuring of labor, characterized by mass unemployment, flexibilization of labor relations as a result of the neoliberal model, resulting in the flattening of wages and the loss of labor rights ${ }^{(4)}$. Conditions that reinforce the results of the study, regarding the valuation of labor as a source of income and subsistence, for this reason the importance of maintaining employment in the face of social and economic pressures of the current conjuncture.

The affinity and/or interest in the health and/or nursing area, according to the interviewees, occurred when they identified themselves with the profession and in the day-to-day living in the work environment, when living with limited situations, and with the feeling of contributing with the health and well-being of the patients, constituting relevant social activity in the life of these professionals, for enabling learning and growth as professionals and human beings.

As for learning, it was evident in the discourses that the exchange of experiences with a diversity of situations of pleasure and suffering contribute to the formation of the professional in terms of essential skills and knowledge. Thus, professional choice must be considered as influenced by the individual's historical background, life-long experiences, as well as the influence of family members and the labor market. The ability to deal with suffering, the conflicts of the profession and ethical values are important aspects in the choice of nursing as a profession. In this perspective, there is a positive interaction between the worker and the physical and social environment of work, with the potential to promote one's own health, physical 
and mental well-being, factors that positively influence productivity ${ }^{(3,13)}$.

When reflecting on the themes related to nursing performance, the pleasure derived from the patient's recovery and the conviviality with the work colleagues, it was verified that the valorization and professional recognition are achieved through actions that aim to improve the health conditions of the patient, act as a source of pleasure and satisfaction of staff and other workers in the occupational field. In this way, working in hospitals and public health is rich and stimulating, not only characterized as a synonym of suffering, but also as a source of pleasure ${ }^{(14)}$.

The recovery of the hospitalized patient in the view of participants is considered a source of pleasure, and it should be emphasized that the goal of any work is the transformation of the object and of the man himself, whose final result is reverted to a material or symbolic reward, insofar as the individual impresses his subjectivity ${ }^{(15)}$.

The difficulties in dealing with the patient's suffering and death and the suffering caused by the inadequate working conditions are in line with studies that discuss the relationship between the psychic burden of work and the frequent coexistence of nursing workers with pain, suffering and death of patients under their care. Other sources of attrition are added, such as shift work, night work, increased work pace, inadequate working conditions, low pay and social deprivation that lead to suffering and illness ${ }^{(16-17)}$.

In addition to the factors pointed out as cause of suffering, in the capitalist system, work has been considered a source of displeasure, causing tension and suffering, preventing the manifestation of creativity and even the enjoyment of results ${ }^{(18)}$.

Currently, one tries to understand the most subjective aspect of the health-disease process, giving special attention to the relation between mental health and work, on the view that certain types or characteristics of work operate in a structuring or decisive way to mental illnesses ${ }^{(19)}$. Suffering at work, triggered by psycho-social risks, especially in the hospital area, causes illness and consequent reduction of the ability of individuals to work, restricted to occupational activities, but also in family and social life. But despite sickened, professionals perform their work with pain, worn and exhausted, characterizing, presenters. There are also problems related to absenteeism, especially those who accumulate more than one job,

\section{Conclusion}

The study showed that the nursing work is a pleasurable activity, to the extent that the staff feel rewarded for contributing to the patient's recovery, acquire knowledge and broaden learning and professional growth. On the other hand, work can also be a source of suffering for workers, for living with the pain, suffering and death of patients.

It is concluded that the enjoyment and experiences of suffering are inherent to the nursing work environment in the hospital environment and contribute to the search for improvements in the work environment and the quality of life of these professionals.

\section{Acknowledgments}

To the Foundation for Research of the State of Rio de Janeiro.

\section{Collaborations}

Barboza PC participated in the project design, analysis and interpretation of data and writing of the article. Pires AS, Pérez Júnior EF, Oliveira EB, Espírito Santo TB and Gallasch CH participated in the project design, analysis and interpretation of data, critical review of the relevant intellectual content and final approval of the version to be published. 


\section{References}

1. Vieira BGM, Moraes LP, Oliveira LA, Rosa LA, Monteiro CB, Passos JP. Prazer e sofrimento na prática laboral dos residentes de enfermagem. Rev EDUC-Facul Duque Caxias [Internet]. 2017 [citado 2018 jun 13];4(1). Disponível em:http://uniesp.edu.br/sites/_biblioteca/ revistas/20180320165520.pdf

2. Conceição MR, Costa MS, Almeida MI, Souza AMA, Cavalcante MBPT, Alves MDS. Quality of life for nurses when teaching professionaly: a study with the Whoqol-bref. Esc Anna Nery. 2012; 2(16):320-5. doi: http://dx.doi.org/10.1590/ S1414-81452012000200016

3. Pires AS, Ribeiro LV, Souza NVDO, Sá CMS, Gonçalves FGA, Santos DM. The permanence in the world of labor of nursing staff with the possibility of retirement. Ciênc Cuid Saúde. 2013; 12(2):338-45. doi: http://dx.doi.org/10.4025/ cienccuidsaude.v12i2.18298

4. Gonçalves FGA, Souza NVDO, Pires AS, Santos DM, D'Oliveira CAFB, Ribeiro LV. Neoliberal model and its effects on the health of the nursing worker. Rev Enferm UERJ [Internet]. 2014 [cited Apr 04, 2018]; 22(4):519-25. Available from: http:// www.facenf.uerj.br/v22n4/v22n4a14.pdf

5. Santos SMP, Sousa V, Rueda JMR. Burnout and organizational climate relationships in hospital workers. ABCS Health Sci. 2015; 40(1):11-5. doi: http://dx.doi.org/10.7322/abcshs.v40i1.697

6. Bardin L. Análise de conteúdo. São Paulo: Edições 70; 2011.

7. Cavalcante RB, Calixto P, Pinheiro MMK. Análise de conteúdo: considerações gerais, relações com a pergunta de pesquisa, possibilidades e limitações do método. Inf Soc Est [Internet]. 2014 [citado 2018 abr 4]; 24(1):13-8. Disponível em:https://search.proquest.com/openview/ d7c0f193d33e3f100687d8c3259a4ed8/1?pqorigsite $=$ gscholar \&cbl=2030753

8. Machado MH, Filho WA, Lacerda WF, Oliveira E, Lemos $\mathrm{W}$, Wermelinger $\mathrm{M}$, et al. Características Gerais da Enfermagem: o perfil sociodemográfico. Enferm Foco. 2016; 7:9-14. doi: http://dx.doi. org/10.21675/2357-707X.2016.v7.nESP.686
9. Siqueira K, Griep RH, Rotenberg L, Costa A, Melo E, Fonseca MJ. Interrelationships between nursing workers' state of nutrition, socio demographic factors, work and health habits. Ciênc Saúde Coletiva. 2015; 20(6):1925-35. doi: http://dx.doi. org/10.1590/1413-81232015206.00792014

10. Machado LSF, Rodrigues EP, Oliveira LMM, Laudano RCS, Nascimento Sobrinho CL. Health problems reported by nursing workers in a public hospital of Bahia. Rev Bras Enferm. 2014; 67(5):684-91. doi: 10.1590/0034-7167.2014670503

11. Karino ME, Felli VEA, Sarquis LMM, Santana LL, Silva SR, Teixeira RC. Workloads and strain processes of nursing workers are teaching hospital. Ciênc Cuid Saúde. 2015; 14(2):1011-8. doi: http://dx.doi.org/10.4025/cienccuidsaude. v14i2.21603

12. Antunes R. Os sentidos do trabalho. São Paulo: Bomtempo; 2014.

13. Rodrigues AL, Barrichello A, Morin EM. The meanings of work to nursing professionals: A multi-method study. Rev Adm Empres. 2016; 56(2):192-208. doi: http://dx.doi.org/10.1590/ S0034-759020160206

14. Cunha LS, Souza NVDO, Gonçalves FGA, Santos DM, Ribeiro LV, Pires AS. Hospital nursing: the dialectics of adapting and improvising in practice. Rev Enferm UERJ. 2016; 24(5):e18835. doi: http://dx.doi.org/10.12957/reuerj.2016.18835

15. Campos JF. David HMSL, Souza NVDO. Pleasure and suffering: assessment of intensivist nurses in the perspective of work psychodynamics. Esc Anna Nery. 2014; 18(1):90-5. doi: http://www. dx.doi.org/10.5935/1414-8145.20140013

16. Prestes FC, Beck CL, Magnano TS, Silva RM. Pleasure-suffering indicators of nursing work in a hemodialysis nursing service. Rev Esc Enferm USP. 2015; 49(3):469-77. doi: http://dx.doi. org/10.1590/S0080-623420150000300015

17. Karhula K, Härmä M, Sallinen M, Hublin C, Virkkala J, Kivimäki M, et al. Job strain, sleep and alertness in shift working health care professionals - a field study. Ind Health. 2013; 51(4):406-16. doi: http:// doi.org/10.2486/indhealth.2013-0015 
18. Alves MGM, Braga VM, Faerstein E, Lopes CS, Jumger W. Modelo demanda-controle de estresse no trabalho: considerações sobre diferentes formas de operacionalizar a variável de exposição. Cad Saúde Pública. 2015; 31(1):208-12. doi: http://dx.doi.org/10.1590/0102-311X00080714

19. Oliveira RD, Neves EB, Kaio $\mathrm{CH}$, Ulbrich L. Afastamento do trabalho em profissionais de enfermagem por etiologias psicológicas. Rev Promoc Saúde. 2013; 26(4):554-62. doi: http:// www.dx.doi.org/S1415-27622005000400004
20. Garcia AB, Haddad MCFL, Dellaroza MSG, Rocha FLR, Pissinati PSC. Strategies used by nursing technicians to face the occupational suffering in an emergency unit. Rev Rene. 2016; 17(2):28592. doi: https://doi.org/10.15253/21756783.2016000200017 